2. Верещагин, Е.М. Язык и культура. / Е.М. Верещагин, В.Г. Костомаров - М.: Индрик, 2005. - 1038 с.

3. Красножонова Е.С. Роль лингвострановедческой компетенции преподавателя иностранного языка при обучении основам межкультурной коммуникации. - Режим доступа к статье: http:// www.pglu.ru/lib/publications/University_Reading/2009/VIII/uch_2009_VIII_00004.pdf._ (дата обращения: 01.11.2021).

4. Томахин, Г.Д. Реалии в культуре и языке // Иностранные языки в школе. - 2001. - № 1. - С. 8-14.

5. Шевченко С.В. Влияние предметов «страноведение» и «лингвострановедение» на формирование межкультурной компетенции в процессе обучения иностранным языкам / С.В. Шевченко, Р.М. Гранкина, М.Р. Манукян. - Глобальный научный потенциал. - 2020. - № 9 (114). - С. 71-73.

\title{
Никитин Г.М. \\ Социализация учащихся профессиональных училищ в период трансформации рынка труда
}

ФГБОУ ВО «Кубанский государственный аграрный университет имени И.Т. Трубилина»

(Россия, Краснодар)

doi: 10.18411/trnio-11-2021-166

\section{Аннотация}

В обществе знаний качественное образование является стартовым капиталом, без которого невозможно полноценное и успешное включение человека в рынок труда. Качественное образование является основой экономики, опирающейся на знания. Цель статьи - отразить имеющуюся ситуацию изменений в России в сфере общего образования, изложить связь социализации человека с проблемами занятости. В практической части статьи будут отражены мнения учащихся, которые связаны с их оценкой получаемого образования и перспективами будущего развития. База исследования: учащиеся профессиональных училищ Краснодара в возрасте от 12 до 17 лет, 93 учащихся. Сроки исследования: сентябрь 2020 - май 2021 года. Метод исследования: частично структурированное интервью.

Ключевые слова: социализация, рынок труда, образование, интернет-технологии, профессиональное развитие.

\section{Abstract}

In a knowledge society, high-quality education is the start-up capital, without which a fullfledged and successful inclusion of a person in the labor market is impossible. Quality education is the backbone of a knowledge-based economy. The purpose of the article is to reflect the current situation of changes in Russia in the field of general education, to outline the connection between human socialization and employment problems. The practical part of the article will reflect the views of students that are related to their assessment of the education they receive and the prospects for future development. Research base: students of vocational schools in Krasnodar aged 12 to 17, 93 students. Terms of research: September 2020 - May 2021. Research method: semi-structured interview.

Keywords: socialization, labor market, education, Internet technologies, professional development.

Социализация является социальным процессом в течение жизни человека, осваивая модели культуры, поведения и то, что общество ожидает от человека [4, 61]. Особое значение имеет активность обучения в раннем детстве и в юношеском возрасте, акцентируя движение человека через первичную и вторичную социализацию. В сущности, движущей силой индивидуального развития является общность жизнедеятельности, которая складывается из переживаний человека, отложений опыта, наблюдений, включая все это в круг интересов человека, включая наличие структуры личности и дееспособность к саморефлексии [3, 69]. 
Процесс социализации также рассматривается как миг в общем ходе жизни, в том числе, и в невзгодах. К тому же необходимо обратить внимание и на то, что в каждую специфическую единицу времени будут доминировать старые и специфические для каждого индивида проблемы, которые и будут определять движение к последующим задачам развития $[2,167]$.

Социализация хода жизни является одной из самых обширных субобластей в исследовании социализации человека. Каждый этап жизни требует освоения определенной общности норм и ожиданий. Каждый этап включает в себя приспособление к новому и освоение требований новой роли $[1,150]$.

На течение жизни человека влияют различные события. В социологии много говорится о том, какое влияние на человека оставляет безработица. В исследованиях о влиянии безработицы на эмоциональные процессы человека констатировано, что человек проходит ряд различных стадий, которые, в свою очередь, зависят от того, насколько человек способен эластично приспособиться к существующей ситуации. Часть безработных вначале чувствует проявление шока, за которыми, в свою очередь, следует оптимистическое видение новых возможностей. В случаях, если такой оптимизм не оправдывается, индивид может стать депрессивным и пессиместически оценивать себя и свои способности быть снова занятым $[3,326]$.

Видение будущего рынка труда ряд социологов объясняет тем, что в будущем будет все больше работников с так называемыми «портфолио». У них будет «портфолио» умений и навыков, которое будет включать подтверждение различного образования и освоения профессий, которые они будут использовать при смене отрасли труда и места работы. К тому же только у немногих людей карьера будет продолжаться в понимании сегодняшнего сплошного потока. Сторонники данного мнения считают, что идея о «работе на всю жизнь» постепенно утрачивает актуальность. Хотя такая ситуация и имеет положительные черты, то есть, человеку не надо будет в течение всей жизни выполнять однообразную работу, а будет возможность творчески разнообразить ход своей работы $[3,366]$.

Вопрос касается того, как такой будущий сценарий «портфолио» влияет на самоощущение молодежи и ход социализации в общем сегодня в профессиональных учебных заведениях, в которых вместе со средним образованием осваивается какая-либо конкретная профессия в течение четырех лет.

В результате проведенного исследования мы получили информацию о мнениях учащихся профессиональных учебных заведений в видении своего профессионального будущего и своей занятости в связи с получаемой профессией.

14\% опрошенной молодежи также выражают довольно безнадежный взгляд на жизнь. К тому же им не очень ясно видение перспективы своей жизни. В различных ответах также открыто проглядываются случаи употребления опьяняющих веществ для «бегства» от жизненных реалий. «Смеюсь над собой, что я бомжиха. О будущей работе не думаю. Сплю. Иду в школу. Делаю татуировку хной. Употребляю алкоголь. Смотрю в зеркало на свою проблематичную фигуру» (Девушка, 16 лет). «Я стараюсь не думать. Иногда использую запрещенные вещества. В это время я не думаю ни о чем» (Девушка, 17 лет). «Я не знаю будет ли у меня работа. Когда я об этом думаю, я много курю. Это уже с 14-летнего возраста. Мама шла впереди и бросила сигарету, я подняла и впервые затянулась» (Девушка, 17 лет). «Я стараюсь вообще не думать о будущем. Не хочу даже представлять то, что мне через год будет 18 лет» (Девушка, 17 лет).

Часть, то есть 30\% участников опроса считают, что в ближайшем или в далеком будущем они поедут жить за границу. К тому же почти все молодые люди в своих мнениях признавали, что они будут продолжать учиться. Хоть и необходимо признать, что намеченная сфера обучения не всегда намечается в связи с уже начатой сферой обучения. «Однозначно поеду за границу. Все так делают. Даже не знаю, надо ли здесь учиться, так как мне сказали, что там надо будет всему учиться заново. Моя мама уже живет за границей, хочу поехать к ней по возможности поскорее. Школа, диплом, оценки для меня не важны. 
Моя проблема - уехать» (Девушка, 18 лет). «Я думаю, что здесь еще буду жить до лета. Тогда я наконец уеду к родителям. Я уже и сейчас часто не посещаю школу, прогуливаю уроки, у меня две неудовлетворительные оценки. Наверно надо будет начинать учиться заново» (Юноша, 16 лет).

В свою очередь 56\% участников опроса признают, что не жалеют о своем выборе. Но необходимо обратить внимание на то, и данная группа участников опроса не связывает свое видение будущего с работой по получаемой специальности. «Хорошо, что я здесь учусь, так как мне выплачивают стипендию. Будущее меня не волнует. Я отверну свои мысли от плохого и горестного. Я на все стараюсь смотреть с хорошей стороны и улыбаюсь. Конечно, надо думать о сложностях» (Юноша, 16 лет).

В результате можно сделать некоторые выводы, что почти треть участников опроса выражают мнение, что в будущем предполагается отправиться жить за границу и не видит возможности связать ход своей будущей жизни, работы со своей страной.

Существенным является тот аспект, что у части молодежи безнадежный взгляд на современную жизнь, они выражают мнение, что забвение от реальных проблем могут предоставить опьяняющие вещества. Конечно, каждый случай является индивидуальным, однако, обобщая, можно сказать, что преобладающие процессы в обществе, то есть, безработица оказывает влияние на эмоциональные процессы человека, и не все могут гибко приспособиться к существующей ситуации.

Предполагая, что опрошенные учащиеся профессиональных учебных заведений детализированно не информированы о сценарии «портфолио», возможном на будущем рынке труда, можно сделать вывод, что большая часть молодежи все же допускает, что в будущем для того, чтобы быть занятым надо будет получить еще какую-нибудь специальность.

Существенным является тот аспект, что как сами учащиеся, так и реальная ситуация на рынке труда в нашей стране свидетельствует о том, что часть полученных профессий не пользуется спросом на рынке труда, и свои замыслы будущего образования молодежь связывает с получением высшего образования по совсем другой профессии.

Положительным аспектом является то, что большинство участников опроса не сожалеют о своем выборе образования. В качестве мотивирующего вместе с тем и признают, что работу по специальности найти будет сложнее, или будешь работать «за копейки», но полученные знания они все же смогут использовать в современной жизни.

$$
* * *
$$

1. Бим Б. Бад Образование в контексте социализации. Педагогика, 1996, №1

2. $\quad$ Гидденс Э. (2005) Социология. Москва: Едиториал, с. 622

3. Никитин Г.М. Онтогносеологические модели социальной реальности в неклассической социальной философии / диссертация на соискание ученой степени кандидата философских наук / Уральский государственный педагогический университет, Екатеринбург, 2006, 174 с.

4. Bryant I., Clifon D. (2007) Sociology. California: Teller Roal - p. 709

5. Elder G.N. (2000) Das Lebensverlaufs - Paradigma: Sozialer Wandel und individuelle Entwicklung. Konstanz: UVK, S. 199

6. Stolley, Karthy S. (2005) The basics of sociology. Greenwood Press - p. 302

\author{
Никитина Е.А. ${ }^{1}$, Никитин Г.М. ${ }^{2}$ \\ Интернет-среда в обучении русскому языку как иностранному \\ ${ }^{1}$ МАОУ СОШ №45 имени Адмирала Федора Ушакова \\ ${ }^{2}$ ФГБОУ ВО «Кубанский государственный аграрный университет имени И.Т. Трубилина» \\ (Россия, Краснодар)
}

doi: 10.18411/trnio-11-2021-167

Аннотация

Особую нишу среди средств информационно-коммуникационных технологий (ИКТ), способных найти свое применение в сфере преподавания русскому языку как иностранному 